\title{
Modelling the Hydration kinetics of kidney beans (Phaseolus vulgaris) in sodium salts using Response surface methodology
}

\begin{abstract}
Nisha Agarwal*
Department of Food Science and Technology, G.B Pant University of Agriculture and Technology, Pantnagar (Uttarakhand), India

Gurmukh Singh

Department of Food Science and Technology, G.B Pant University of Agriculture and Technology, Pantnagar (Uttarakhand), India

B.K. Kumbhar

Post Harvest Process and Food Engineering, G. B Pant University of Agriculture and Technology, Pantnagar (Uttarakhand), India

${ }^{*}$ Corresponding author. E-mail: 25nishaagarwal@gmail.com

\section{Abstract}

The present work investigated the effect of salt solutions of sodium chloride, and sodium bicarbonate on the water uptake by kidney beans (Phaseolus vulgaris) at different temperatures $\left(30,45\right.$ and $60^{\circ} \mathrm{C}$ ). Thirty-five soaking solutions were prepared using $\mathrm{NaCl}$ and $\mathrm{NaHCO}_{3}$ to find the optimum soaking treatment and time to maximise the hydration. Hydration kinetics of kidney beans was studied in different concentrations of the salt solutions and at different temperatures by the method of weight gain until equilibrium conditions were attained. Response surface methodology was used to design the experiments and to optimize the levels for minimum soaking time and to maximize the hydration. The soaking solutions affected the mass transfer in both seed coat and cotyledon, demonstrating changes on both proteins and polysaccharides. Increasing the temperature from 30 to $60{ }^{\circ} \mathrm{C}$ in sodium chloride solution and sodium bicarbonate solution $(0.5,1.0$ and $1.5 \%$ concentration) decreased the soaking time from $>225 \mathrm{~min}$ and $225 \mathrm{~min}$ to $82.5 \mathrm{~min}$ and 73.5 min respectively to achieve around $80 \%$ hydration. Beans soaked in sodium bicarbonate solution exhibited higher hydration rates than in distilled water followed by sodium chloride solution at the same salt concentration. Soaking for about three hours at $30^{\circ} \mathrm{C}$ resulted in maximum hydration. The optimum soaking treatment was found to be in a salt solution containing $1.10 \% \mathrm{NaCl}$ and $0.92 \% \mathrm{NaHCO}_{3}$ at $30^{\circ} \mathrm{C}$ which resulted in a soaking time of $193.45 \mathrm{~min}$. This work demonstrated a simple and non-tedious approach for enhancing the hydration process of grains.
\end{abstract}

Keywords: Hydration, Kidney bean, Response surface methodology, Salt solution

\section{Article Info}

https://doi.org/

10.31018/jans.v12i1.2234

Received: February 21, 2020

Revised: March 6, 2020

Accepted: March 9, 2020

\section{How to Cite}

Agarwal, N. et al. (2020)

Modelling the Hydration kinetics of kidney beans (Phaseolus vulgaris) in sodium salts using Response surface methodology. Journal of Applied and Natural Science, 12 (1): $42-52$

https://doi.org/10.31018/ jans.v12i1.2234

\section{INTRODUCTION}

The consumption of kidney beans (Phaseolus vulgaris L.) is primarily for their pods and seeds (Choung et al., 2003), and are widely used in Asian countries in traditional foods. They are used in various processed foods such as bakery products, salads, and canned food and are considered to be versatile dietary ingredients (Nciri et al., 2015). Cereals and legume processing often involve hydration of seeds first to facilitate cooking or canning operations. Thus, water adsorption into seeds is of both theoretical and practical interest to grain processing industries (Hsu, 1983; Taiwo et al., 1998; Schoeninger et al. 2017; Miano and Augusto, 2018).

Dry Beans (Phaseolus vulgaris L.) require a long cooking time to achieve the desired digestibility
(Uebersax et al., 1991). Therefore, hydration of beans before cooking is necessary to decrease the cooking time and increase the drained weight (Taiwo et al., 1998; Mustafa et al., 2015). Besides reducing the cooking time, it also results in a softer drained texture and partial removal of oligosaccharides, stachyose and raffinose responsible for flatulence (Nelson and Hsu, 1985; Abd El-Hady and Habiba 2003). There are also some reports on the optimization of the soaking condition of black gram dal in order to reduce the flatugenic sugar content (Rakshit et al.,2015). Soaking is a time-consuming process that involves the diffusion of water into the grain (Engels et al., 1986). Thus, soaking at room temperature may provoke microbial spoilage (Miano and Augusto, 2018), which affects the quality attributes (such as color, taste, and smell) of the product (Bello et al., 2004). So 
several attempts have been made to shorten it. Many (Kon,1979; Piergiovanni, 2011; Oliveira et al., 2013; Miano et al. 2015) employed soaking at elevated temperature for reducing the soaking time. However, it resulted in significant losses of total solids, nitrogenous compounds, total sugars, calcium, magnesium, and water-soluble vitamins.

Vacuum filtration techniques have also been employed to accelerate the soaking of lima beans (Rockland and Metzler, 1967) and soyabean (Xiao et al., 2015). Numerous studies have reported the beneficial effects of soaking in salt solutions before cooking or using various salt solutions in the cooking of pulses. Few studies, however, concluded that the sodium salts in water did not significantly affect the amount of water absorbed by beans, but the $\mathrm{pH}$ of the solution is a critical determinant (Varriano- Marston and De Omana, 1979 and Avila et al., 2015).

From the processing and engineering standpoint, it is required not only to know the time required to attain equilibrium moisture content but also the effect of processing variables and the prediction of soaking time under given conditions. Various models have been used to predict the quantitative analysis of water absorption for cereal grains, but the suitability for applying these models to describe the absorption in legumes remains to be determined. A good model can replace experiments that may be difficult to perform and can aid in the process scale-up (Clark, 1978). Therefore, the aim of the present investigation was (1) to study the effect of various soak solutions of sodium salt, their concentration and the temperature on hydration kinetics of beans (2) to find out a suitable model which fits the hydration kinetics of beans and (3) to optimize (minimize) the soaking time of beans in mixed salt solution.

\section{MATERIALS AND METHODS}

Dry kidney beans (Phaseolus vulgaris L.) of Chitra cultivar were procured from the local market in Pantnagar, India. Beans were sorted manually for removing small, split, and defected beans. Beans were stored at room temperature $\left(23-24^{\circ} \mathrm{C}\right)$ in airtight plastic containers to prevent moisture changes during storage.

Experimental Plan: Response Surface Methodology involving designing of experiments, selection of levels of variables, fitting mathematical model, and finally selecting variable levels by optimizing the response (Khuri and Cornell, 1987) was employed in the present study. The general factorial and box Behnken design was used to design the experiments. In general factorial, two independent variables - salt concentration and temperature at three levels were used. Inbox Behnken design (Tables 1 and 2), three independent variables at three levels were used. Independent variables included salt concentrations of sodium chloride
$(0.5,1.0$ and $1.5 \%)$, salt concentrations of sodium bicarbonate $(0.5,1.0$ and $1.5 \%)$ and temperature $\left(30,45\right.$ and $\left.60^{\circ} \mathrm{C}\right)$.

Determination of moisture content: Dry beans were ground in a domestic grinder, and the resultant bean flour was sieved through a $1 \mathrm{~mm}$ screen. Ten gram of the flour in triplicates was dried to a constant weight in an oven at $100^{\circ} \mathrm{C}$, and the moisture content was determined using AOAC (1984) method.

Determination of water absorption during soaking: Ten gram of dry beans were soaked in $50 \mathrm{ml}$ soak solutions using a thermostatically controlled water bath at three soaking temperatures: 30,45 , and $60^{\circ} \mathrm{C}$. Water absorption was recorded every $15 \mathrm{~min}$. initially due to rapid water uptake and then at $30 \mathrm{~min}$. and one hour due to a decline in the water absorption rate as equilibrium conditions were reached. After the specified time interval, beans were removed from soaking solutions, spread over the tissue paper to remove superficial water, and weighed. The weight gain was recorded (Wood and Harden, 2006) and the beans were put back into the soaking solution, maintained at the required temperature. Water absorption was recorded until there was insignificant difference between two consecutive weights. Experiments were conducted in triplicates, and the results reported as $\mathrm{g} \mathrm{H}_{2} \mathrm{O} / 100 \mathrm{~g}$ dry beans (\% dwb).

Mathematical Modelling: Mathematical equations were developed to relate the amount of water absorbed during hydration to the hydration time for different soaking temperatures, salts, and salt concentration considered in the study. Various models were analyzed using the CURVEFIT software and the best fit model for the data was fitted into the primary response (hydration rate, y). The adequacy of the model was tested using the coefficient of determination $\left(R^{2}\right)$. The constants $(a, b)$ of the model were, thereafter, determined using NLREG software. These values were further used to evaluate the secondary response $x$ (hydration time) for 80 percent hydration (y) using the model. The regression equation was then evaluated for 80 percent hydration rate. A complete secondorder model was fitted into the response (hydration time) for mixed solutions. The adequacy of the model was tested using a coefficient of determination $\left(R^{2}\right)$, Fisher's F-test and lack of fit test. The model was then used to interpret the effects of variables. Contour plots were drawn for showing the effect of independent variables on the response and to select the range of variables for optimum process. The hydration conditions were then optimized using Design Expert 8.0.3.1 where the hydration time and temperature were minimized. A second order response function for three independent variables has the following form:

$$
Y=\beta_{0}+\sum_{i=1}^{K} \beta_{1} X_{1}+\sum_{i=1}^{K} \beta_{i i} X_{i}^{2}+\sum_{i=1}^{K-1} \sum_{j=i+1}^{K} \beta_{i j} X_{i} X_{j} \ldots \ldots \ldots \ldots \ldots . . . . .
$$


Where,

$\beta_{0}, \beta_{\mathrm{ii}}, \beta_{\mathrm{ij}}$ are constants

$\mathrm{X}_{\mathrm{i}}, \mathrm{X}_{\mathrm{j}}$ are variables (coded)

\section{RESULTS AND DISCUSSION}

The hydration by beans at different temperatures, in individual and combined salt solution are shown in Tables 3, 4 and 5.

Effect of soaking time: The water absorption curves (Fig 1 and 2) initially showed a high hydration rate followed by a decline in later stages, which is characteristic of moisture sorption behaviour. This is attributed to the gradual filling of capillaries at the surface of seed coats and at the hilum of black beans and Andean lupins (Hsu et al., 1983; Miano et al., 2015) in the initial phases which increased the water uptake. This is followed by a decline in water absorption due to cumulative effects of increased solute extraction, filling of free capillaries and intermicellar spaces with water (Phlak et al., 1989; Sayar et al., 2001; Miano and Augusto, 2015). Also with prolonged soaking time, the amount of water absorbed stabilized (Taiwo et al., 1998; Wood and Harden, 2006) in legumes due to resisted swelling by the unsolvated structural network of solids which leads to the development of internal pressure and thereby less swelling for the same degree of moisture absorbed (Singh and Kulshreshtha, 1987; Wood and Harden, 2006).

Table 1. Experimental variables for soaking treatments, their coded and uncoded (actual) values.

\begin{tabular}{lllll}
\hline Variables & Code & \multicolumn{3}{c}{ Coded level } \\
\cline { 2 - 5 } & & $\mathbf{- 1}$ & $\mathbf{0}$ & $\mathbf{+ 1}$ \\
\hline NaCl concentration (\%) & $\mathrm{X}_{1}$ & 0.5 & 1.0 & 1.5 \\
NaHCO $_{3}$ concentration (\%) & $\mathrm{X}_{2}$ & 0.5 & 1.0 & 1.5 \\
Temperature $\left({ }^{\circ} \mathrm{C}\right)$ & $\mathrm{X}_{3}$ & 30 & 45 & 60 \\
\hline
\end{tabular}

Effect of temperature: Beans soaked at $60^{\circ} \mathrm{C}$ approached equilibrium faster than at $30^{\circ} \mathrm{C}$. Also, there was a decrease in the maximum water uptake of beans (Fig.1). Similar results were reported previously (Taiwo et al., 1998). These effects are possibly modulated due to increased mass transfer resulted due to altered cell membrane permeability as well as increased gas pressure in the interior of kidney beans (Abu-Ghannam, 1998).

Effect of salt: Soaking in $\mathrm{NaHCO}_{3}$ solution over a temperature range of $30-60^{\circ} \mathrm{C}$ resulted in a more rapid and greater water uptake than beans hydrated in $\mathrm{NaCl}$ at the same salt concentration (Fig 2). This could be due to the degradation of pectic substances, decreased proportion of calcium pectate resulting from the chelation of calcium, and increased charge density of proteins resulting from ionization of amino acid side chains at high $\mathrm{pH}$. This results in increased content of soluble nitrogen, as reported in black beans (Varriano-Marston and De Omana, 1979). Increased water uptake by soaking in $\mathrm{NaHCO}_{3}$ solution was reported previously also in faba beans and yam beans (Haladjian et al., 2003; Aminigo and Metzger, 2005; Avila et al., 2015).

Effect of salt concentration: It was found that soaking in increased concentrations of $\mathrm{NaCl}$ and $\mathrm{NaHCO}_{3}$ at higher temperatures decreased the hydration rate significantly (Fig. 1c and 1f) (Kader, 1995) contrary to the one reported by Avila et al., 2015 in cowpeas. This may be due to increased osmotic gradient across the cotyledon membranes resulting due to the mutual effect of increased salt concentration in the soaking water and more leached solids at a higher temperature (Onyeike and Uzogara, 2000)

Optimizing the soaking time in mixed salt solution: The model, $y=a x^{b}$ (power-law) was

Table 2. Experimental design matrix (Box Behnken design) for soaking treatment and levels in coded and uncoded form.

\begin{tabular}{|c|c|c|c|c|}
\hline \multirow[b]{2}{*}{ Experiment } & \multirow[b]{2}{*}{ No. } & \multicolumn{3}{|c|}{ Coded (real values) } \\
\hline & & $\begin{array}{c}\mathbf{X}_{1} \\
(\mathrm{NaCl} \text { concentration })\end{array}$ & $\begin{array}{c}\mathbf{X}_{2} \\
\left(\mathrm{NaHCO}_{3} \text { concentration }\right)\end{array}$ & $\begin{array}{c}\mathbf{X}_{\mathbf{3}} \\
\text { (Temperature) }\end{array}$ \\
\hline 1 & & -1 & -1 & 0 \\
\hline 2 & & +1 & -1 & 0 \\
\hline 3 & & -1 & +1 & 0 \\
\hline 4 & & +1 & +1 & 0 \\
\hline 5 & & -1 & 0 & -1 \\
\hline 6 & & +1 & 0 & -1 \\
\hline 7 & & -1 & 0 & +1 \\
\hline 8 & & +1 & 0 & +1 \\
\hline 9 & & 0 & -1 & -1 \\
\hline 10 & & 0 & +1 & -1 \\
\hline 11 & & 0 & -1 & +1 \\
\hline 12 & & 0 & +1 & +1 \\
\hline 13 & & 0 & 0 & 0 \\
\hline 14 & & 0 & 0 & 0 \\
\hline 15 & & 0 & 0 & 0 \\
\hline 16 & & 0 & 0 & 0 \\
\hline 17 & & 0 & 0 & 0 \\
\hline
\end{tabular}


found to be the best fit for the data where $y$ is the water absorbed and $x$ is the hydration time. The constants $a$ and $b$ at different conditions with the corresponding correlation coefficients are shown in Table 6. In a mixed salt solution of sodium chloride and sodium bicarbonate, minimum soaking time for 80 percent hydration was observed with Expt. 7 (Table 5) which corresponds to 0.5 per cent $\mathrm{NaCl}\left(\mathrm{X}_{1}=-1\right), 1.0$ per cent $\mathrm{NaHCO}_{3}\left(\mathrm{X}_{2}=0\right)$ at $60^{\circ} \mathrm{C}\left(\mathrm{X}_{3}=+1\right)$ and soaking time of $62.64 \mathrm{~min}$. The maximum soaking time (221.98 $\mathrm{min})$ was seen for Expt. 10 which corresponds to 1.0 per cent sodium chloride $\left(X_{1}=0\right), 1.5$ per cent sodium carbonate $\left(X_{2}=+1\right)$ at $30^{\circ} \mathrm{C}\left(X_{3}=-1\right)$.

The results of the regression analysis are presented in Table 7. The coefficient of determination $\left(R^{2}\right)$ for the regression model of hydration time in sodium chloride and sodium bicarbonate was 93.10, which implied that the model could account for 93.10 percent data. Lack of fit was insignificant, which implied that the data could be well explained and interpreted by the model. It was seen (Table 8) that the effect of sodium chloride and sodium bicarbonate was insignificant, but the temperature had a significant effect on hydration time $(p<0.01)$ as having been reported earlier (Kader, 1995). The negative coefficient of $X_{3}$ indicated that the hydration time decreased with the increase in temperature, whereas the positive coefficient of $X_{1}$ and $X_{3}$ indicated that hydration time increased with an increase in levels of sodium chloride and sodium bicarbonate. The predictive equation is given below:

$Y=124.39+5.40 X_{1}+1.47 X_{2}-65.57 X_{3}+$ $2.91 \mathrm{X}_{1} \mathrm{X}_{2}+8.74 \mathrm{X}_{1} \mathrm{X}_{3}-2.63 \mathrm{X}_{2} \mathrm{X}_{3}+10.17 \mathrm{X}_{1}^{2}$ $+14.78 X_{2}^{2}+4.12 X_{3}^{2}$

Where,

$\mathrm{X}_{1}, \mathrm{X}_{2}, \mathrm{X}_{3}$ are the coded variables for sodium chloride (percent) level, sodium bicarbonate (percent) level and temperature $\left({ }^{0} \mathrm{C}\right)$.

ANOVA showing the effect of independent variables at a linear, quadratic and interactive level and the individual effect of variables are shown in Table 9 and 10. It shows that the effect was significant at a linear level only $(p<0.01)$ and the effect of temperature was most followed by sodium chloride and sodium bicarbonate. The contour plots are shown in Fig.3. These curves are plotted to understand the interaction of the variables and to determine the optimum level of each variable for maximum response. The higher sodium chloride concentration and sodium bicarbonate concentration in a salt solution, increased the hydration time (Fig. 3a). An increase in the temperature leads to a decrease in hydration time, while for both sodium chloride concentration (Fig. 3b) and sodium bicarbonate concentration (Fig 3c), the hydration time decreases initially and then increases with increase in concentration. The optimized levels of the variables are given in Table 11. Beans soaked

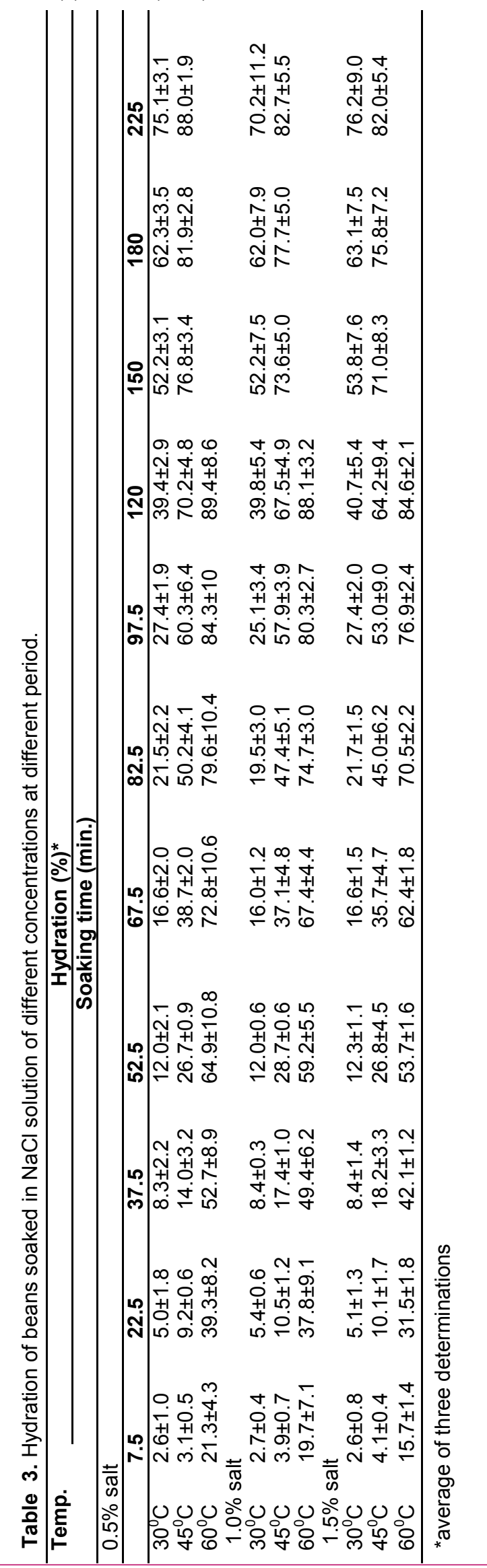




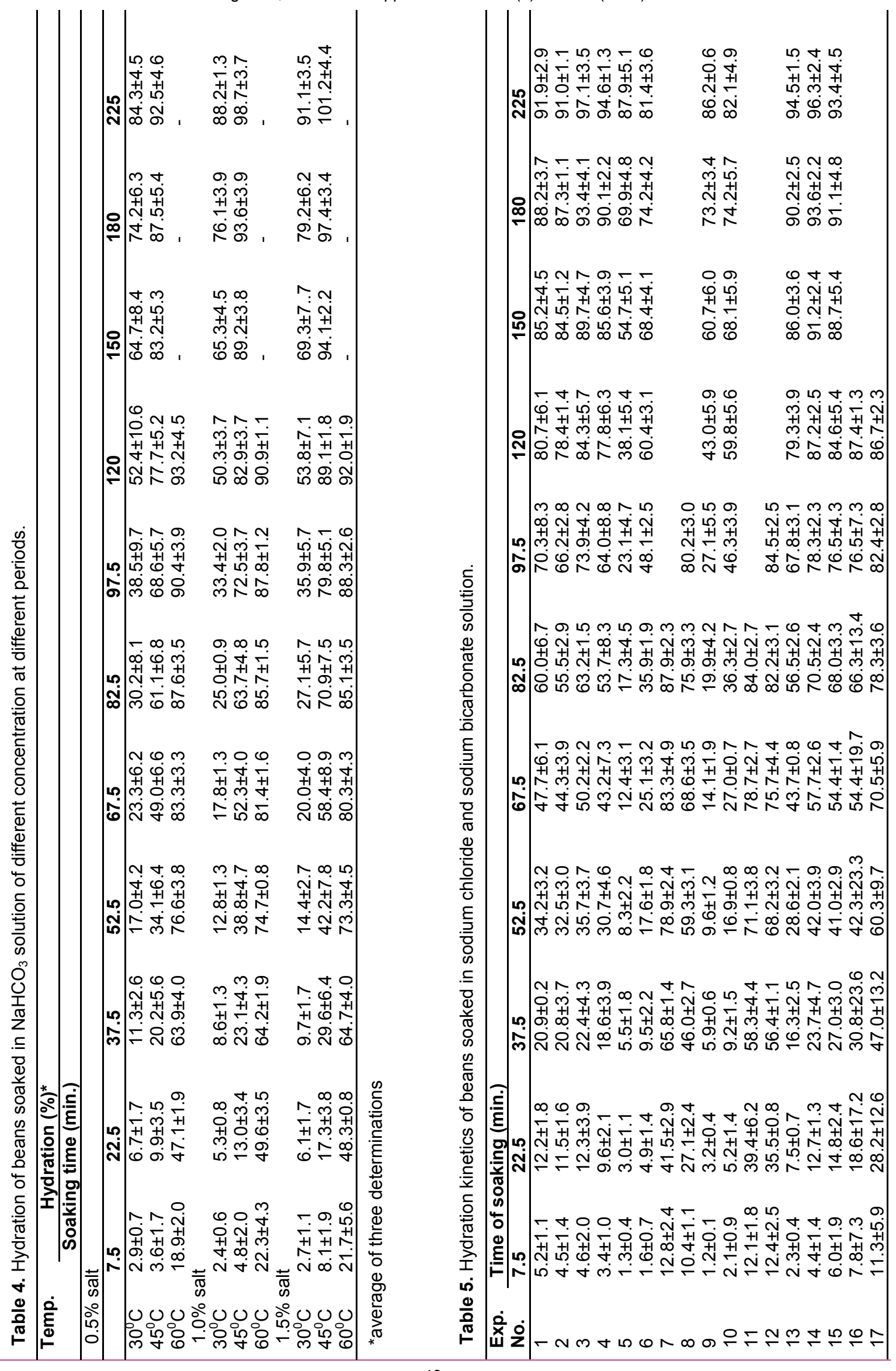


Agarwal, N. et al. / J. Appl. \& Nat. Sci. 12(1): 42 - 52 (2020)
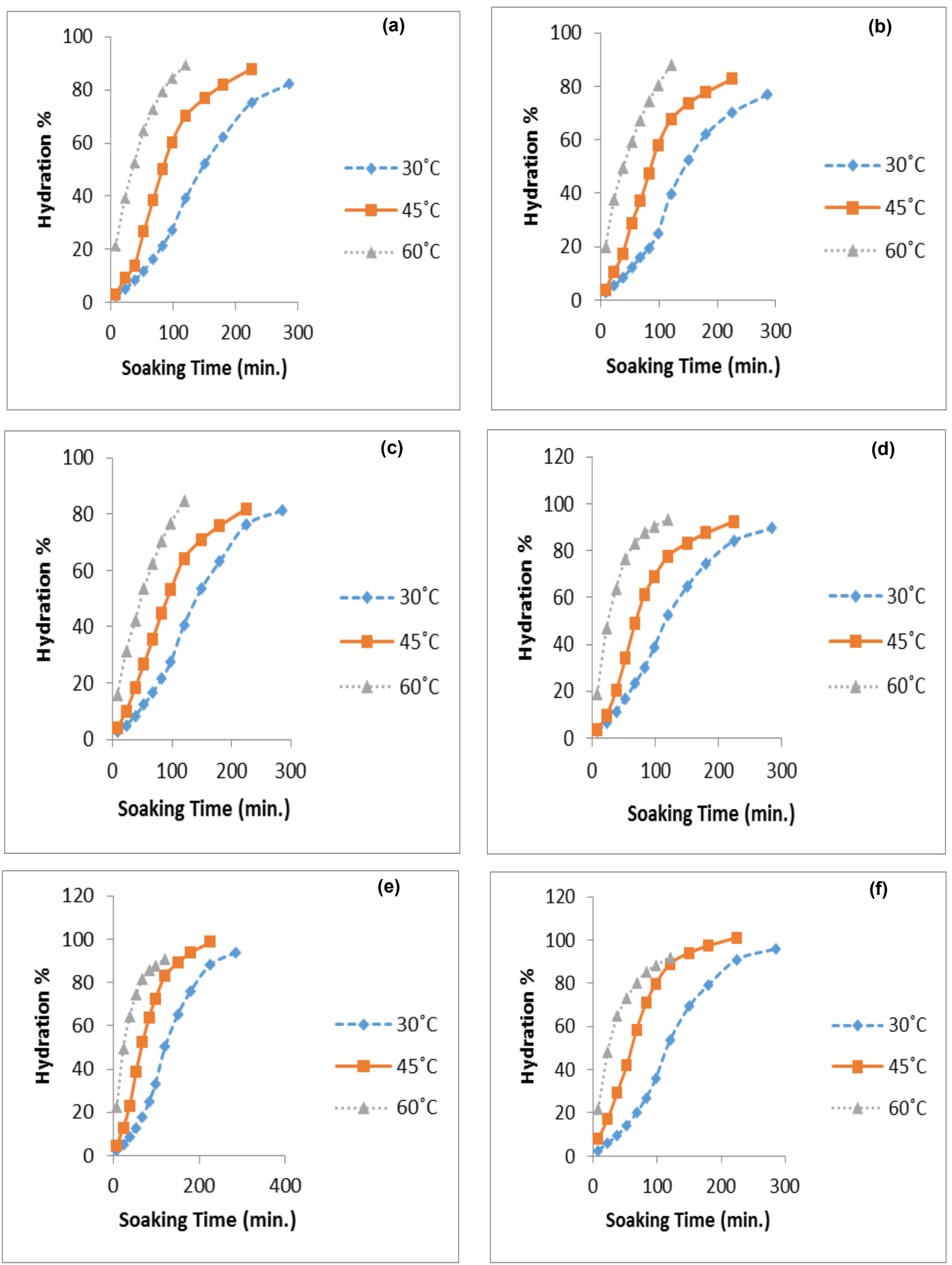

Fig. 1. Effect of temperature on soaking in (a) $0.5 \% \mathrm{NaCl}$ solution, (b) $1.0 \% \mathrm{NaCl}$ solution, (c) $1.5 \% \mathrm{NaCl}$ solution, (d) $0.5 \% \mathrm{NaHCO}_{3}$ solution, (e) $1.0 \% \mathrm{NaHCO}_{3}$ solution and (f) $1.5 \% \mathrm{NaHCO}_{3}$ solution. 
Agarwal, N. et al. / J. Appl. \& Nat. Sci. 12(1): 42 - 52 (2020)
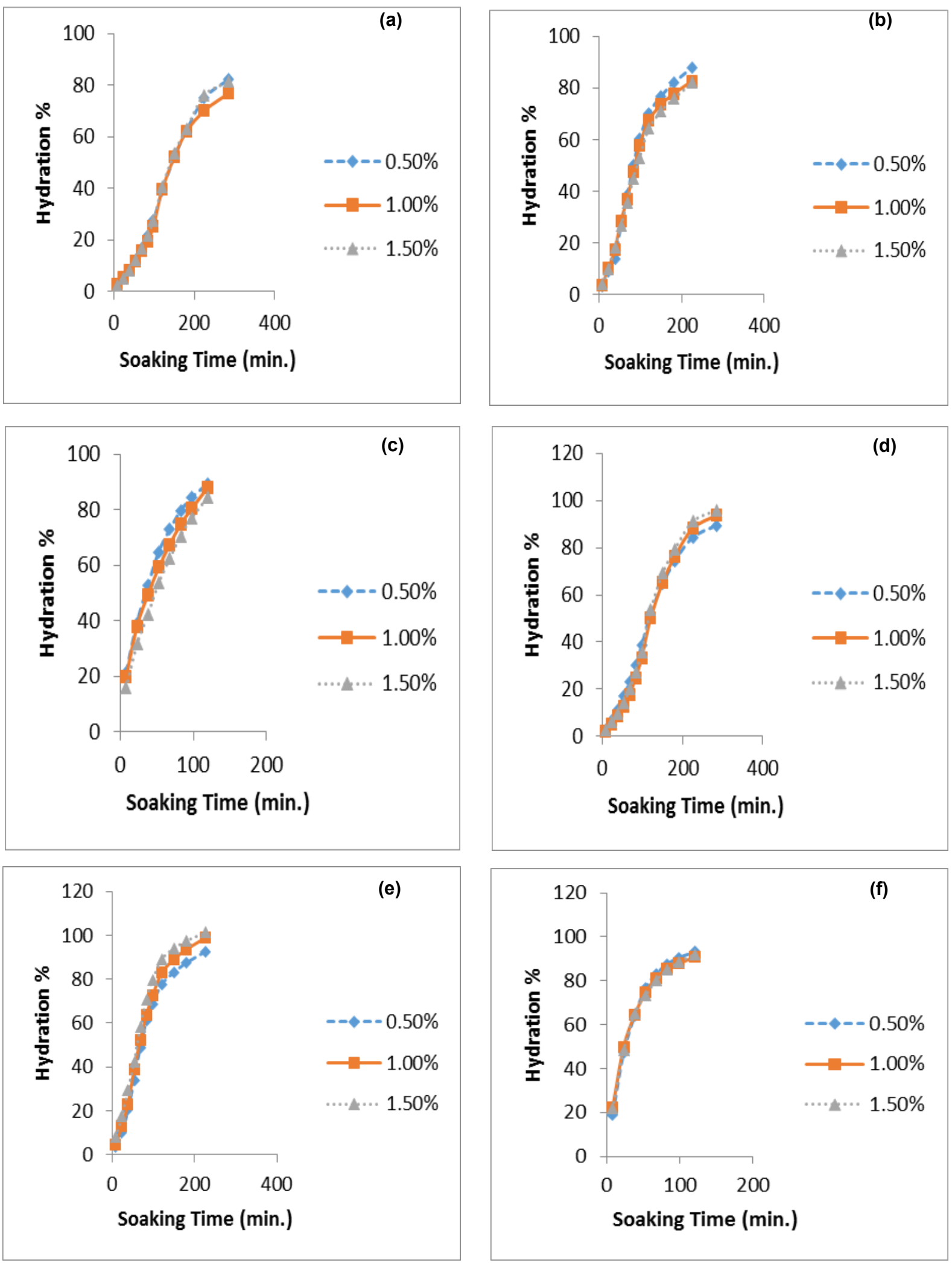

Fig. 2. Effect of $\mathrm{NaCl}$ concentration on hydration rate at temperatures (a) $30^{\circ} \mathrm{C} \mathrm{(b)} 45^{\circ} \mathrm{C}$ (c) $60^{\circ} \mathrm{C}$ and effect of $\mathrm{NaHCO}_{3}$ concentration at temperatures (d) $30^{\circ} \mathrm{C}$ (e) $45^{\circ} \mathrm{C}$ (f) $60^{\circ} \mathrm{C}$. 
Table 6. Regression Analysis of the relationship between hydration time and hydration rate of beans when regression equation : $y=a x^{b}$.

\begin{tabular}{llll}
\hline Treatment & $\begin{array}{l}\text { Soaking } \\
\text { temperature } \\
\left({ }^{0} \mathbf{C}\right)\end{array}$ & $\begin{array}{l}\text { Regression } \\
\text { constants }\end{array}$ & $\mathbf{R}^{2}$ \\
\hline Control & 30 & $0.34,1.00$ & 0.967 \\
& 45 & $1.88,0.74$ & 0.953 \\
& 60 & $9.47,0.49$ & 0.982 \\
$0.5 \% \mathrm{NaCl}$ & 30 & $0.27,1.03$ & 0.97 \\
& 45 & $1.52,0.77$ & 0.94 \\
& 60 & $8.91,0.49$ & 0.989 \\
$1.0 \% \mathrm{NaCl}$ & 30 & $0.30,0.99$ & 0.96 \\
& 45 & $1.80,0.73$ & 0.95 \\
& 60 & $7.59,0.52$ & 0.998 \\
$1.5 \% \mathrm{NaCl}$ & 30 & $0.29,1.01$ & 0.968 \\
& 45 & $1.57,0.75$ & 0.964 \\
$0.5 \% \mathrm{NaHCO}$ & 60 & $4.98,0.59$ & 0.998 \\
& 30 & $0.68,0.88$ & 0.964 \\
& 45 & $2.58,0.68$ & 0.928 \\
$1.0 \% \mathrm{NaHCO}_{3}$ & 60 & $11.99,0.45$ & 0.943 \\
& 30 & $0.36,1.00$ & 0.955 \\
$1.5 \% \mathrm{NaHCO}_{3}$ & 35 & $2.97,0.67$ & 0.939 \\
& 60 & $13.8,0.41$ & 0.945 \\
& 45 & $0.46,0.97$ & 0.953 \\
& 60 & $4.32,0.60$ & 0.929 \\
& 30 & $13.04,0.42$ & 0.958 \\
\hline
\end{tabular}

Table 7. Regression Analysis of the relationship between hydration time and hydration rate of beans when regression equation : $y=a x^{b}$.

\begin{tabular}{llll}
\hline Treatments & $\begin{array}{l}\text { Regression } \\
\text { constants }\end{array}$ & $\mathbf{R}^{2}$ & $\begin{array}{l}\text { Hydration } \\
\text { time }\end{array}$ \\
\hline$-1,-1,0$ & $2.76,0.67$ & 0.925 & 150.72 \\
$+1,-1,0$ & $2.34,0.69$ & 0.936 & 156.64 \\
$-1,+1,0$ & $2.83,0.68$ & 0.927 & 136.23 \\
$+1,+1,0$ & $1.79,0.75$ & 0.945 & 153.797 \\
$-1,0,-1$ & $0.03,1.50$ & 0.989 & 204.86 \\
$+1,0,-1$ & $0.58,0.93$ & 0.952 & 197.26 \\
$-1,0,+1$ & $6.41,0.61$ & 0.945 & 62.64 \\
$+1,0,+1$ & $3.57,0.69$ & 0.981 & 89.98 \\
$0,-1,-1$ & $0.06,1.36$ & 0.898 & 202.15 \\
$0,+1,-1$ & $1.08,0.79$ & 0.935 & 221.98 \\
$0,-1,+1$ & $5.42,0.63$ & 0.969 & 69.88 \\
$0,+1,+1$ & $6.04,0.59$ & 0.963 & 79.17 \\
$0,0,0$ & $1.76,0.76$ & 0.926 & 152.1 \\
$0,0,0$ & $3.86,0.62$ & 0.902 & 132.65 \\
$0,0,0$ & $4.11,0.60$ & 0.914 & 138.44 \\
$0,0,0$ & $1.23,0.89$ & 0.997 & 105.34 \\
$0,0,0$ & $4.89,0.62$ & 0.968 & 93.42
\end{tabular}

${ }^{*}-1,0,+1$ are the coded levels of variables $x_{1}(\mathrm{NaCl}$ concentration) , $x_{2}\left(\mathrm{NaHCO}_{3}\right.$ concentration), $\mathrm{x}_{3}$ (Temperature), ${ }^{* *}$ Hydration time for $80 \%$ hydration

in 1.10 percent sodium chloride and 0.92 percent sodium bicarbonate resulted in a minimum soaking time of $193.45 \mathrm{~min}$.
Table 8. Results of the regression analysis showing effect of sodium chloride, sodium bicarbonate and temperature on hydration time of the beans.

\begin{tabular}{lll}
\hline Factor & Coefficient Estimate & p-value \\
\hline Intercept & 124.39 & $0.003^{* *}$ \\
$\mathrm{X}_{1}$ & 5.40 & 0.46 \\
$\mathrm{X}_{2}$ & 1.47 & 0.84 \\
$\mathrm{X}_{3}$ & -65.57 & $<0.001^{* *}$ \\
$\mathrm{X}_{1} \mathrm{X}_{2}$ & 2.91 & 0.78 \\
$\mathrm{X}_{1} \mathrm{X}_{3}$ & 8.74 & 0.40 \\
$\mathrm{X}_{2} \mathrm{X}_{3}$ & -2.63 & 0.80 \\
$\mathrm{X}_{1}{ }^{2}$ & 10.17 & 0.32 \\
$\mathrm{X}_{2}{ }^{2}$ & 14.78 & 0.17 \\
$\mathrm{X}_{3}{ }^{2}$ & 4.12 & 0.68 \\
$\mathrm{R}^{2}(\%)$ & 93.10 & \\
F-value & 10.50 & \\
Lack of fit & Ns & \\
\hline
\end{tabular}

**Significant at $1 \%$ level of significance; ns - nonsignificant; $X_{1}$ : sodium chloride conc., $X_{2}$ : sodium bicarbonate conc., $\mathrm{X}_{3}$ : Temperature

\section{Conclusion}

In the present study, RSM was used to optimize the soaking time and soaking treatments for kidney beans to enhance the hydration process. The optimal values were obtained for responses by solving the regression equations of independent variables using Design-Expert software. The water absorption of beans (Phaseolus vulgaris L.) increased with time and temperature. It is also affected by the type of salt and its concentration in soaking solution. Soaking in sodium chloride, sodium bicarbonate or ammonium carbonate solution at an elevated temperature decreased the hydration time while an increase in concentration increased the hydration time. The effect of increasing temperature was significant $\left(60{ }^{\circ} \mathrm{C}\right)$, but the effect of salts $(1.5 \%)$ was insignificant on hydration time in mixed salt solutions of sodium chloride and sodium bicarbonate. The optimum soaking treatment was found to be in a salt solution containing $1.10 \% \mathrm{NaCl}$ and $0.92 \% \mathrm{NaHCO}_{3}$ at $30^{\circ} \mathrm{C}$ resulted in a soaking time of $193.45 \mathrm{~min}$.

\section{REFERENCES}

1. Abd El-Hady, E.A., Habiba, R.A. (2003). Effect of soaking and extrusion conditions on antinutrients and protein digestibility of legume seeds. Lebensm Wiss U-Technology, 36, 285-293.

2. Abu Ghannam, N. (1998). Modeling textural changes during the hydration process of red beans. Journal of Food Engineering, 38, 341-352.

3. Aminigo, E.R., and Metzger, L.E. (2005). Pretreatment of African Yam Bean (Sphenostylis stenocardia): Effect of Soaking and Blanching on the Quality of African Yam Bean Seed. Plant Foods for Human Nutrition, 60, 165-171.

4. AOAC. (1984). Official Methods of Analysis, 14th ed. Association of Official Analytical Chemists, Washington. DC 
At optimum point

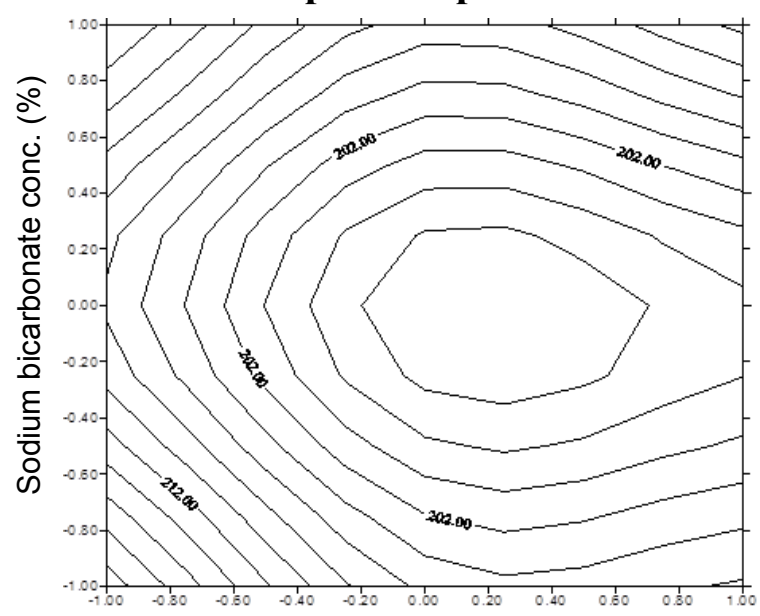

Sodium chloride conc. (\%)

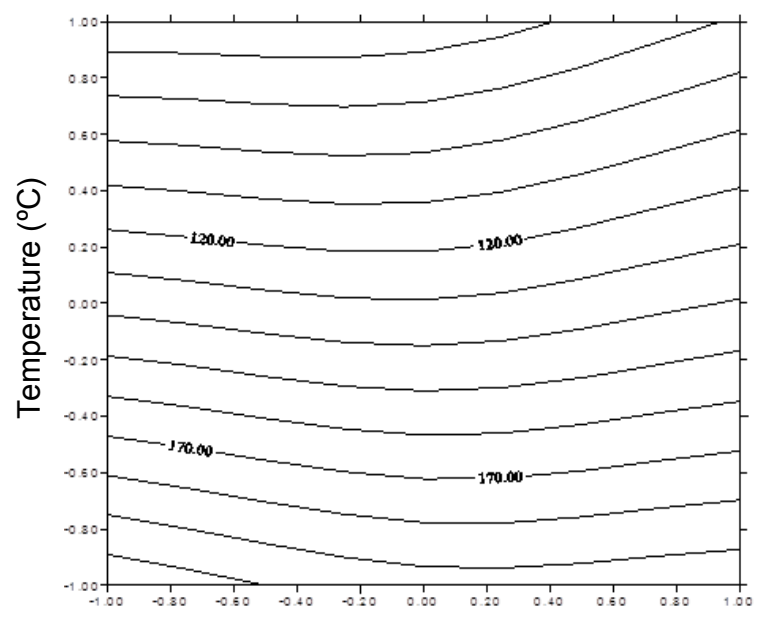

Sodium chloride conc. (\%)

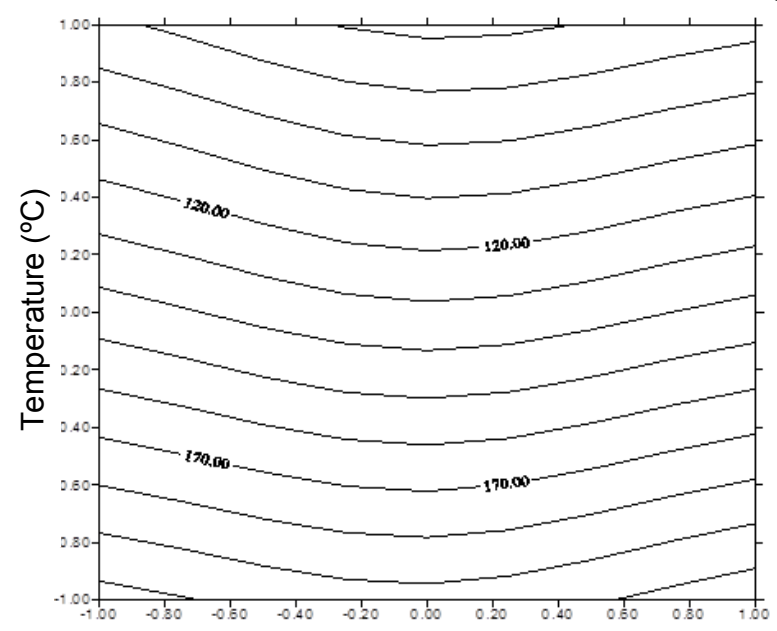

Sodium bicarbonate conc. (\%)
At centre point

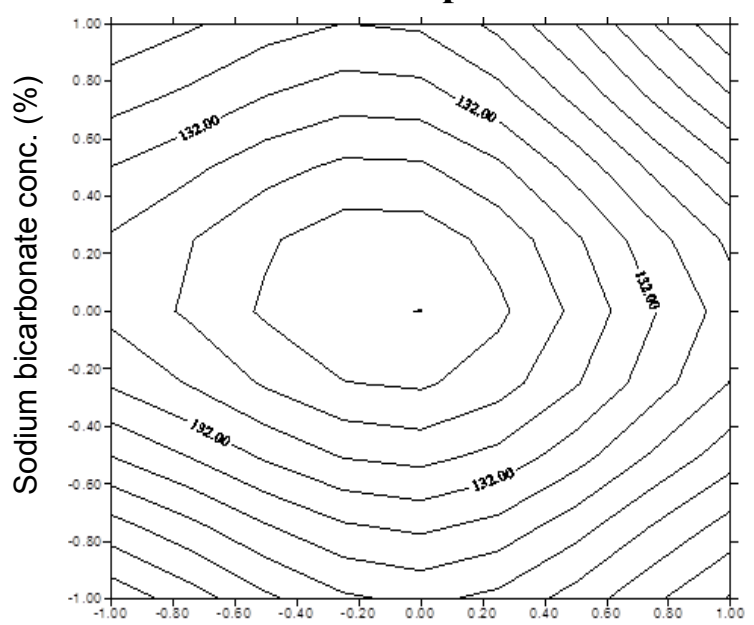

Sodium chloride conc. (\%)

(a)

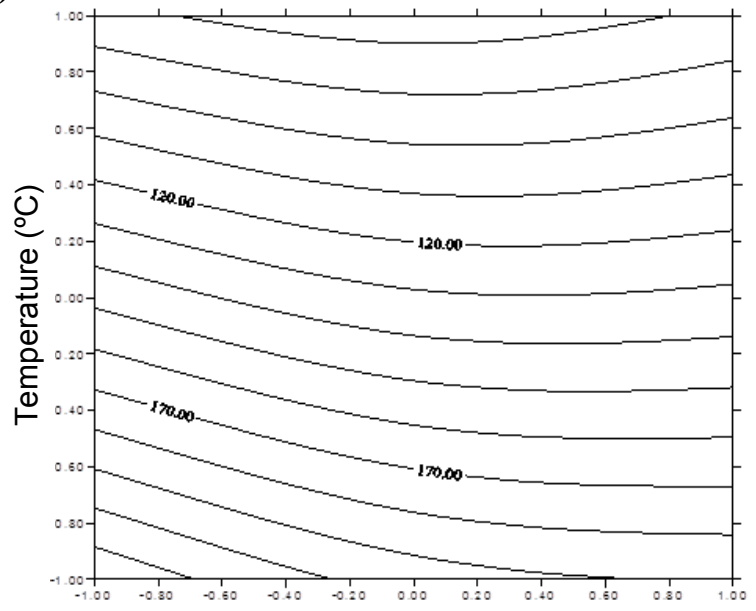

Sodium chloride conc. (\%)

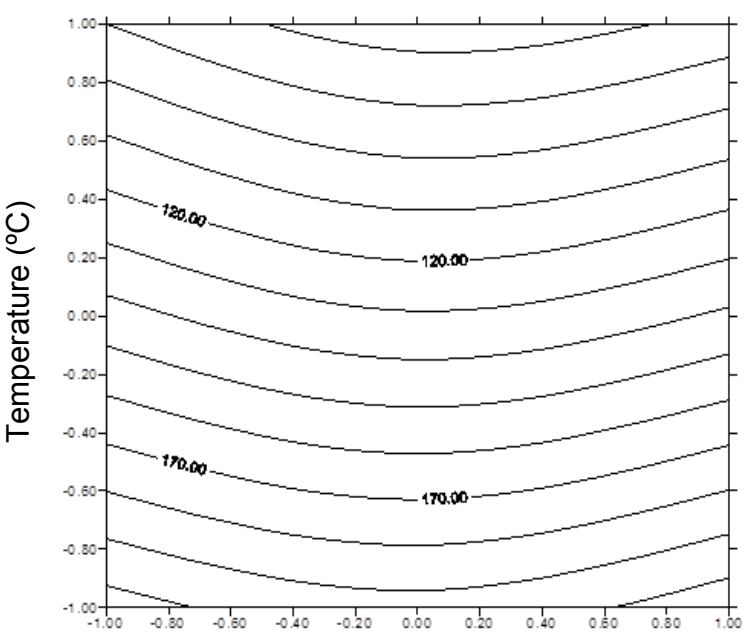

Sodium bicarbonate conc. (\%)

(c)

Fig. 3. Contour plots showing effect of sodium chloride, sodium bicarbonate and temperature on hydration time. 
Agarwal, N. et al. / J. Appl. \& Nat. Sci. 12(1): 42 - 52 (2020)

Table 9. ANOVA showing effect of sodium chloride, sodium bicarbonate and temperature on hydration time.

\begin{tabular}{lcccc}
\hline Source & $\begin{array}{c}\text { Degree of free- } \\
\text { dom }\end{array}$ & $\begin{array}{c}\text { Sequential sum of } \\
\text { squares }\end{array}$ & Mean square & F-value \\
\hline Model & 9 & 36570.93 & 4063.44 & $10.50^{* *}$ \\
Linear & 3 & 34648.96 & 11549.65 & $32.42^{* *}$ \\
Quadratic & 3 & 1555.09 & 518.36 & 0.3365 \\
Interactive & 3 & 366.89 & 122.30 & 0.8339 \\
Error & 4 & 2355.52 & 588.88 & \\
\hline
\end{tabular}

**Significant at $1 \%$ level of significance

Table 10. Individual effect of variables on hydration time.

\begin{tabular}{llll}
\hline Variables & $\begin{array}{l}\text { Total sequential sum of } \\
\text { squares }\end{array}$ & $\begin{array}{l}\text { Average Sequential sum of } \\
\text { squares }\end{array}$ & F-value \\
\hline $\mathrm{NaCl} \mathrm{conc.}(\%)$ & 1008.46 & 252.12 & 266.96 \\
$\mathrm{NaHCO}_{3}$ conc. $(\%)$ & 999.26 & 249.81 & 264.53 \\
Temperature ( $\left.{ }^{\circ} \mathrm{C}\right)$ & 34802.5 & 8700.63 & 9213 \\
\hline
\end{tabular}

Table 11. Optimized levels of variables (coded and uncoded).

\begin{tabular}{lll}
\hline Variables & Levels & Hydration time \\
\hline Sodium chloride $(\%)$ & $0.19(1.10 \%)$ & $193.45 \mathrm{~min}$ \\
Sodium bicarbonate $(\%)$ & $-0.16(0.92 \%)$ & \\
Temperature $\left({ }^{\circ} \mathrm{C}\right)$ & $-1.00\left(30^{\circ} \mathrm{C}\right)$ & \\
\hline
\end{tabular}

*values in parentheses are the uncoded levels of variables

5. Avila, B.P., Satos dos Santos, M., Nicoletti, A.M., Alves, G.D., Elias, M.C., Monks, J., and Gularte, M.A. (2015). Impact of Different Salts in Soaking Water on the Cooking Time, Texture, and Physical Parameters of Cowpeas. Plant Foods for Human Nutrition, 70(4), 463-469.

6. Bello, M., Tolaba, M.P., Suarez, C., 2004. Factors affecting water uptake of rice grain during soaking. Lebensmittel-Wissenschaft und -Technologie, 37, 811-816.

7. Choung, M.G., Choi, B.R., An, Y.N., Chu, Y.H., Cho, Y.S. (2003). Anthocyanin profile of Korean cultivated kidney bean (Phaseolus vulgaris L.). J. Agric. Food Chemistry, 50 (24), 7040-7043

8. Clark J.P. (1978). Mathematical modelling in sterilization processes. Food Technology, March 73-75.

9. Engels, C., Hendrickx, M., De Samblanx, S., De Gryze, I., Tobback, P., 1986. Modeling water diffusion during long grain rice soaking. Journal of Food Engineering, 5, 55-73.

10.Haladjian, N., Fayad, R., Toufeili, I., Shadarevian, S., Sidahmed, M., and Baydoun, E. (2003). pH, Temperature and Hydration kinetics of faba beans (Vicia faba L.). Journal of Food Process and Preservation, 27:920

11.Hsu, K.H., Kim, C.J., and Wilson, L.A. (1983). Factors affecting water uptake of soyabeans during soaking. Cereal Chemistry, 60, 208-211.

12.Kader, Z.M.A. (1995). Study of some factors affecting water absorption by faba beans during soaking. Food Chemistry, 53(3), 235-238.

13.Khuri, A.I., and Cornell, J.A. (1987). Response surfaces, designs, and analysis. New York: Marcel Dekker.

14.Kon, S. (1979). Effect of soaking temperature on cooking and nutritional quality of beans. Journal of Food Science, 44, 1329-1334.

15.Miano A.C, Augusto, P.E.D. (2015). From the sigmoidal to the downward concave shape behavior during the hydration of grains: effect of the initial moisture content on Adzuki beans (Vigna angularis).
Food Bioprod Process, 96:43-51.

16.Miano, A.C and Augusto, P.E.D. (2018). The hydration of grains: A critical review from description of phenomena to process improvements. Comprehensive Reviews in Food Science and Food Safety, 7, 352-370

17.Miano, A.C., Garcia, J.A., and Augusto, P.E.D. (2015). Correlation between morphology, hydration kinetics and mathematical models on Andean lupin (Lupinus mutabilisSweet) grains. LWT - Food Science and Technology, 61:290-98.

18.Mustafa, A., Ceylan, I., Sevik, S., and Dogan, H. (2015). Decreasing the Cooking time of dry beans without lowering the quality. Journal of Polytechnic, 18(1), 29-34.

19.Nciri, N., Cho, N., Bergaoui, N., Mhamdi, F.E., Ammar, A.B., Trabelsi, N., Sami, Z., Fathi, G., Ben, M.A., Haj, S.F., Ben, A.F., 2015. Effect of white kidney beans (Phaseolus vulgaris L. var. Beldia) on small intestine morphology and function in Wistar rats. Journal of Medicinal Food, 18 (12), 1387-1399.

20.Nelson, R.L., and Hsu, K.H. (1985). Effects of leachate accumulation during hydration in a thermo-screw blancher on the water absorption and cooked texture of navy beans. Journal of Food Science, 50 (4), 782788.

21. Oliveira, A.L., Colnaghi, B.G., Silva, E. Zd., Gouvea, I.R., Vieira, R.L., and Augusto, P.E.D. (2013). Modelling the effect of temperature on the hydration kinetics of adzuki beans (Vigna angularis). Journal of Food Engineering, 118, 417-20.

22. Onyeike E.N. and Uzogara, S.G. (2000)Effect of soaking in salt solutions on water absorption, ph and cooking time of African yam bean seeds (Sphenostylis stenocarpa hochst ex. A. Rich harms). Global journal of pure and applied sciences, 6 (1), 67 $-73$

23.Phlak, L.C., Caldwell, K.B., and Stanley, D.W. (1989). Comparison of methods used to characterize water imbibition in hard-to-cook beans. Journal of Food Science, 54, 326-329. 
Agarwal, N. et al. / J. Appl. \& Nat. Sci. 12(1): 42 - 52 (2020)

24.Piergiovanni AR. (2011). Kinetic of water adsorption in common bean: considerations on the suitability of Peleg's model for describing bean hydration. Journal of Food Processing and Preservation, 35: 447-52.

25.Rakshit, M. Sharma, A. Saha, J. and Sarkar, P.K (2015). Optimization of the soaking condition of blackgram to minimize the flatogenic sugar content in blackgram based products. LWT - Food Science and Technology, 63(2), 814-820.

26.Rockland, L.B., and Metzler, E.A. (1967). Quickcooking lima and other dry beans. Food Technology, 21, 344-348.

27.Sayar, S., Turhan, M., and Gunasekaran, S. (2001). Analysis of chickpea soaking by simultaneous water transfer and water-starch reaction. Journal of Food Engineering, 50, 91-98

28.Schoeninger, V., Coelho, S.R.M., and Bassinello, P. (2017). Industrial processing of canned beans. Ciencia. Rural, 47(5)

29.Singh, B.P.N., and Kulshrestha, S.P. (1987). Kinetics of water absorption by soybean and pigeon pea grains. Journal of Food Science, 52, 1538-1544.

30.Taiwo, K.A., Akanbi, C.T., and Ajibola, O.O. (1998). Regression relationships for the soaking and cooking properties of two cowpea varieties. Journal of Food Engineering, 37, 331-344.

31.Uebersax, M.A., Ruengsakulrach, S., and Occena, L.G. (1991). Strategies and procedures for processing dry beans. Food Technology, 44, 104-111.

32. Varriano-Marston, E., and De Omana, E. (1979). Effects of sodium salt solutions on the chemical composition and morphology of black beans (Phaseolus vulgaris). Journal of Food Science, 44, 531-536.

33.Wood, J. A. and Harden, S. (2006). A Method to estimate the hydration and swelling properties of chickpeas (Cicer arietinum L.). Journal of Food Science, 71(4): E190 - E195.

34.Xiao, G., Gong, J., Ge, Q., and You, Y. (2015). Effect of vaccum soaking on the properties of soyabean (Glycine max (L.) Merr.). International Journal of Food Engineering. 11(1), 151-155. 